\title{
Household Solid Waste Management Strategy in Danau Teluk Sub-District, Jambi City
}

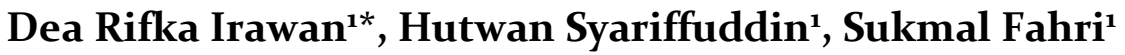 \\ ${ }^{1}$ Department of Environmental Science, Faculty of Postgraduate, Universitas Jambi, Jl. Arif Rahman \\ Hakim, Kampus Unja Telanai, Jambi, Indonesia 36361 \\ *Corresponding Author, email: dearifka.irawan@gmail.com

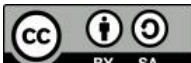

\begin{abstract}
Danau Teluk Sub-District is one of the sub-districts in Jambi City. The waste production produced by Danau Teluk Sub-District based on DLH Jambi City data in 2020 reached 8,793.99 kg/day with 12,563 people. In Danau Teluk Sub-District, the production of managed waste reached 71.05\%, and unmanaged waste reached $28.95 \%$. Compared to other sub-districts, the percentage of the managed waste is the lowest, and the percentage of the unmanaged waste is the highest. This research is conducted on influencing factors using distribution frequency and multiple linear regression, community and government involvement using distribution frequency and chi-square, and determining strategic priorities in household solid waste management using SWOT. Based on the study results, two factors influence household solid waste management: behavior and knowledge of local regulations. Two factors related to the management of household solid waste, namely implementation, and supervision, then the strategic are to carry out waste reduction starting from the source by reducing the use of goods that produce waste and providing data on waste management that is easily accessible to the public such as through social media, websites, television advertisements, and bulletin boards.
\end{abstract}

Keywords: household, solid waste, strategy, waste, waste management

\section{Introduction}

Based on UU No. 18 of 2008 concerning Household Waste Management, ideally, everyone in the management of household waste and similar household waste must reduce and handle waste in an environmentally sustainable. The waste reduction includes activities to limit waste generation, recycle waste, and reuse waste. Waste management includes waste sorting activities, collection to waste collection sites (TPS) or Integrated Waste Processing Sites (TPST), transportation to landfills, and processing and final waste processing (UU No. 18 of 2008: Waste Management, 2008). Compared to those regulations, this is not in line with the existing condition of solid waste management, especially households in Danau Teluk Sub- District. Household solid waste management in Danau Teluk SubDistrict still relies on the end-of-pipe approach. Waste is collected, transported, and disposed of to the TPS and landfill in Danau Teluk Sub-District and the waste cleaners. In addition, it was found that people in the Danau Teluk Sub-District who have houses in the form of buildings using wooden pile foundations have a culture of throwing their waste under their houses. 
on public health and the environment, if it is done continuously and there are still people who throw waste into the river, which can result in the accumulation of waste and environmental pollution in the river, this unmanaged waste can have an impact on the environment in the form of water, soil, air, and health pollution if it is carried out continuously. Based on unstructured interviews with the village heads in Danau Teluk Sub-District, several other households have solid waste management problems. The community's interest in managing household solid waste still lacks due to the unavailability of segregated facilities and infrastructure, land area TPS construction lacks because there are already resident settlements. It is challenging to build TPS because the area during the rainy season often floods, waste transportation rites of 2 times per day are considered insufficient so that at night the waste can interfere with the aesthetics of the environment. Other than that, in Danau Teluk Sub-District, the production of managed waste only reached $71.05 \%$, and unmanaged waste (treated without access) reached $28.95 \%$ (DLH Jambi City, 2020). Compared to other sub-districts in Jambi City, the percentage of the managed waste is the lowest, and unmanaged waste (treated without access) is the highest (DLH Jambi City, 2021).

The problem of absolute waste must be handled jointly between the government and the community itself. Therefore, awareness and mutual commitment are needed to change attitudes, behavior, and environmentally cultured ethics. As an effort to raise awareness in handling environmental problems, especially waste, and to create a residential environment that is clean and environmentally friendly, therefore, a paradigm shift in waste management must be carried out by reducing the volume of waste from the source by selecting or processing with simple technology such as composting at household scale or environmental scale and community participation in waste management coordinated by nongovernmental groups (KSM) (Artiningsih, 2008). The government has a role as a policy regulator, and as a service provider in waste management (Jati, 2013), and society participate in the decision-making process, implementation, and supervision of the implementation of solid waste management carried out by the government and local governments (Permenpupr No. 3 of 2013: Implementation of Infrastructure and Facilities in Handling Household Waste and Similar Household Waste, 2013) in good household waste management requires the involvement of both. It is necessary to identify the factors that correlate with the way of managing household waste, such as education level, income level, behavior, knowledge of local regulations, and willingness to pay waste retribution in household solid waste management (Riswan et al., 2011), to support the implementation of household solid waste management. Furthermore, an appropriate strategy for household waste management can be determined.

It is necessary to identify the factors that influence the management of household solid waste in Danau Teluk Sub-District, analyze how the involvement of the community and government in managing household solid waste in Danau Teluk Sub-District, and determine how the strategy for managing household solid waste in the Danau Teluk Sub-District to be more optimal. Based on the phenomena in Danau Teluk District, the condition of household solid waste management has not been optimal, so it is necessary to determine strategic priorities to manage household solid waste in Danau Teluk District is more optimal. Therefore, this study will examine the management of household solid waste in Danau Teluk Sub-District, identify the factors that influence the management of household solid waste, analyze the involvement of the community and government in managing household solid waste, and determine the priority of solid waste management strategies that can be applied in Teluk Danau District.

\section{Methods}

The approach used in this research is quantitative methods. The samples were determined by using the probability sampling technique. The method used to determine the number of respondents (n) in this study used the Slovin formula as follows (Sugiyono, 2017):

$\mathrm{n}=\frac{N}{1+\left(N \cdot e^{2}\right)}$

Information :

$\mathrm{n} \quad=$ number of respondents 
$\mathrm{N} \quad=$ total population (head of family)

e $\quad=$ expected precision $(10 \%)$

The number of samples is distributed in several villages using proportionate stratified sampling technique. The variables that will be observed in this study are the independent variable and the dependent variable. The operational definition of a variable is:

Table 1. Operational Definition of Variables

\begin{tabular}{lll}
\hline \multicolumn{2}{l}{ Independent Variables: Factors Affecting Household Solid Waste Management } \\
\hline $1 . \quad$ Education $\left(\mathrm{X}_{1}\right)$ & $\begin{array}{l}\text { The last education level of the respondent measured based } \\
\text { on the respondent's formal education level } \\
\text { The number of work results in the form of money earned byth } \\
\text { respondent every month, measured in rupiah based on } \\
\text { the respondent's monthly average wage }\end{array}$ \\
2. $\quad$ Income $\left(\mathrm{X}_{2}\right)$ & $\begin{array}{l}\text { Knowledge, attitudes, and actions of respondents, measuredb } \\
\text { on the level of knowledge, attitudes, and actions of } \\
\text { respondents towards waste management solid household }\end{array}$ \\
3. $\quad$ Behavior $\left(\mathrm{X}_{3}\right)$ & $\begin{array}{l}\text { Respondents general understanding of applicable regulations, } \\
\text { measured based on the respondent's level of understanding }\end{array}$ \\
4. $\quad$ Knowledge of Local & Regulations $\left(\mathrm{X}_{4}\right)$ & $\begin{array}{l}\text { Respondent's willingness to pay the household solid waste } \\
\text { management fee measured based on the respondent's level of } \\
\text { willingness }\end{array}$ \\
5. & Retribution $\left(\mathrm{X}_{5}\right)$ &
\end{tabular}

\section{Independent Variable: Community and Government Involvement in Household Solid Waste} Management

6. $\quad$ Decision Making $\left(\mathrm{X}_{6}\right)$

Involvement in meetings and planning processes in the implementation of household solid waste management by the respondent measured based on participation in this matter by the respondent

7. Implementation $\left(\mathrm{X}_{7}\right)$

Involvement in the implementation and management of household solid waste by the respondent measured based on the implementation in this case by the respondent

8. $\quad$ Supervision $\left(\mathrm{X}_{8}\right)$ Involvement in evaluating or assessing the shortcomings of the implementation of household solid waste management bythe respondent measured based on the respondent's participation in this matter

9. Regulator Involvement in carrying out duties and authorities is measured based on the suitability of duties and authoritieswith applicable regulations by the respondent.

10. Service Providers Involvement in providing services for the continuity of household solid waste management measured based on the existing services that respondents have provided

\begin{tabular}{lll}
\hline \multicolumn{2}{l}{ Dependent Variable: Household Solid Waste Management } \\
\hline 11. & Household Solid Waste & $\begin{array}{l}\text { Waste management consists of waste reduction and waste } \\
\text { Management }(\mathrm{Y})\end{array}$ \\
\hline
\end{tabular}

The source of data used by researchers is primary data, which is data obtained directly from respondents. Primary data is a questionnaire, the results of observations and interviews. Secondary data is data obtained from data collection techniques that support primary data sourced from document studies such as journals, books, reports, regulations, and research-related. Data analysis to identify influencing factors in household solid waste management using descriptive statistical analysis with frequency distribution and graphs and inferential statistics with multiple linear regression. Data analysis 
used descriptive statistical analysis with frequency distribution and graphs and inferential statistics with chi-squared to analyze community and government involvement in household solid waste management. Data analysis is optimal using SWOT analysis to determine household solid waste management strategy to be implemented in the Danau Teluk Sub-District, Jambi City. How to test the influence of the independent variable on the dependent variable by using multiple linear analysis. Then it is stated in the regression equation as follows (Sugiyono, 2015):

$\mathrm{Y}=\mathrm{a}+\mathrm{b}_{1} \mathrm{X}_{1}+\mathrm{b}_{2} \mathrm{X}_{2}+\ldots+\mathrm{bnXn}$

Information:

$\mathrm{Y}=$ subject in the predicted dependent variable

$\mathrm{a}=$ price of $\mathrm{Y}$ when price of $\mathrm{X}=\mathrm{o}$ (constant price)

$\mathrm{b}=$ direction number or regression coefficient that shows the number of increases or decreases in the variable dependent, which is based on changes in the independent variable. If $(+)$ the direction of the line is up, if (-) the direction of the line is down

$\mathrm{X}$ = subject in the independent variable that has a certain value

The basis for decision making is to use the probability significance number, namely:

a. If the probability $>0.05$ then the research hypothesis (Ho) is accepted.

b. If the probability $<0.05$ then the research hypothesis (Ho) is rejected.

Statistical tests were performed using the chi-square formula (chi-square)(Suliyanto, 2014):

$X^{2}=\sum_{i=1}^{k} \frac{(f o-f e)^{2}}{f e}$

Information:

$\mathrm{X}_{2}=$ chi squared (chi-square)

Fo $=$ observed frequency

$\mathrm{Fe}=$ expected frequency

The basis for making hypothetical decisions is based on a significance level ( $\alpha$ value) of $95 \%$ :

a. If the probability value $>(0.05)$ then the research hypothesis $(\mathrm{Ho})$ is accepted.

b. If the probability value (o.05) then the research hypothesis (Ho) is rejected.

\section{Result and Discussion}

\subsection{Factors Affecting Household Solid Waste Management in Danau Teluk Sub-District}

In this study, household solid waste management factors are education, income, behavior, knowledge of local regulations, and willingness to pay retribution. Based on the results of the respondent's, it can be seen in Table 2:

Table 2 Respondent's Factors Affecting Household Solid Waste Management Frequency Distribution

\begin{tabular}{lll}
\hline Education & Frequency $(\mathbf{F})$ & Percentage (\%) \\
\hline Low (Primary/Junior Highschool) & 12 & 12 \\
Medium (Senior Highschool) & 70 & 71 \\
Higher (Diploma/Bachelor) & 17 & 17 \\
\hline Total & $\mathbf{9 9}$ & $\mathbf{1 0 0}$ \\
\hline Income & Frequency (F) & Percentage (\%) \\
\hline Low (<Rp. 2,630,000) & $\mathbf{6 2}$ & 63 \\
Medium (Rp. 2,630,000-3,815,000) & 31 & 31 \\
High (> Rp. 3,815,000) & & 6 \\
\hline Total & 99 & $\mathbf{1 0 0}$ \\
\hline Behavior & $\mathbf{F r e q u e n c y ~ ( F ) ~}$ & Percentage (\%) \\
\hline Low & $\mathbf{1 0}$ & $\mathbf{1 0}$ \\
Medium & 68 & 69 \\
\hline
\end{tabular}


Based on Table 2, it was found that the respondents in the low category of education (graduated from elementary school/junior high school) were $12 \%$, the medium category (high school graduate) was $71 \%$, and the high category (graduated diploma/bachelor) was $17 \%$. These results indicate that the education level of the respondents is relatively high and can still absorb information well. Respondents dominated respondent's education in the medium category (graduated from high school). In research conducted by Gofur (2020), the environment has a very supportive role in the sustainability of the level of education taken by the generations in it. If many individuals are aware of the importance of education in the environment, then automatically, other individuals will follow this phenomenon because they see individuals who continue their education can survive with changing circumstances.

The income level of respondents with income levels in the low category $(<R$ p.2,630,00o) was $63 \%$, the medium category (Rp.2,630,000-3,815,00o) was 31\%, and the high category (>Rp.3.815,000) was $6 \%$. This condition indicates that the income level of respondents is still low. Respondents dominate the income of respondents in the low category with occupations, namely self-employed. Pertiwi (2015) said that the wages of a job in various regions and within an area are not always the same. One of the factors that give rise to these differences is the imperfection in labor mobility. Geographical and institutional factors cause the imperfection of worker mobility.

The behavior of respondents in the low category is $10 \%$, the medium category is $69 \%$, and the high category is $21 \%$. This result indicates that the respondent's behavior is quite good. Respondents dominate the behavior of respondents in the medium category with high school and undergraduate education levels. In a study conducted by Syamaun, 2019, the environment (including culture) significantly influences a person's personality. Personality, he said, is nothing but a consistent pattern of behavior that describes the history of reinforcement that we experience. Everyone has a particular pattern of attitudes and behavior due to the community's reinforcement (reinforcement, reward) for these attitudes and behaviors, not for other attitudes and behaviors.

Knowledge of local regulations by respondents with knowledge of local regulations in the low, medium, and high categories as much as $20 \%, 62 \%$, and $18 \%$, respectively. This result indicates that the respondent's knowledge of local regulations is quite good. Respondents dominate knowledge of local regulations from respondents in the medium category with a high school education level. In research conducted by Riswan (2011) that socialization plays a role in the knowledge of regulations. If the regulations are enforced, this will have a deterrent effect on people who violate them. Enforcement of this law will have a positive impact on better household waste management.

Willingness to pay retribution by respondents are $0,30 \%$, and $70 \%$ under low, medium, and high categories, respectively. This condition indicates that the willingness of respondents to pay levies is relatively high. Willingness to pay retribution respondents with a high category is dominated by respondents with self-employed jobs and civil servants. In a study conducted by Riswan, 2011, people aware of the importance of environmental cleanliness are willing to pay retribution as long as they get good waste management services from the government. Based on research on the factors that influence household solid waste management, a factor with the highest category is the willingness to pay retribution.

\subsection{The Influence of Factors Affecting Household Solid Waste Management on Household Waste Management}

This analysis is used to determine whether there is an influence between the independent variables on the dependent variable. This analysis was performed using multiple linear regression statistical tests (multiple linear regression). Based on the results of multiple linear regression statistical tests in Table 3 obtained education with a significance value of 0.735 ( $\mathrm{sig}>0.05)$. It can be concluded that statistically, there is no effect on household solid waste management. Income level has a significance value of 0.363 ( sig>0.05), which can be concluded that statistically, there is no effect on household solid waste management. Behavior level has a significance value of 0.001 ( $\mathrm{sig}<0.05)$ which means that there is 
an influence on household solid waste management. Knowledge regarding regional regulations and willingness to pay have influence household solid waste management since they have a significant level of more than 0.05. Obtained knowledge of local regulations with the highest beta value of 0.581 , it can be concluded that statistically the most dominant influence on household solid waste management. Based on research on the influence of factors that influence household solid waste management on household solid waste management, two factors influence household solid waste management, namely behavior and knowledge of local regulations with knowledge of local regulations having the most dominant influence on household solid waste management.

Table 3 Analysis of the Influence of Factors Affecting Household Solid Waste Management

\begin{tabular}{|c|c|c|c|c|c|c|}
\hline \multicolumn{7}{|c|}{ Coefficients } \\
\hline \multirow{3}{*}{\multicolumn{2}{|c|}{ Model }} & \multirow{2}{*}{\multicolumn{2}{|c|}{$\begin{array}{l}\text { Unstandardized } \\
\text { Coefficients }\end{array}$}} & \multirow{3}{*}{$\begin{array}{l}\text { Standardized } \\
\text { Coefficients } \\
\text { Beta }\end{array}$} & \multirow[t]{3}{*}{$\mathbf{t}$} & \multirow[t]{3}{*}{ Sig. } \\
\hline & & & & & & \\
\hline & & B & Std. Error & & & \\
\hline \multirow[t]{7}{*}{1} & (Constant) & -14.890 & 10.312 & & -1.444 & o. 152 \\
\hline & Education & 0.278 & 0.820 & 0.028 & 0.340 & 0.735 \\
\hline & Income & 0.780 & 0.853 & 0.076 & 0.913 & 0.363 \\
\hline & Behavior & 0.567 & 0.167 & 0.254 & 3.402 & 0.001 \\
\hline & $\begin{array}{l}\text { Knowledge of } \\
\text { Regional }\end{array}$ & 1.723 & 0.222 & 0.581 & $7 \cdot 747$ & 0.000 \\
\hline & Regulations & & & & & \\
\hline & $\begin{array}{l}\text { Willingness to Pay } \\
\text { Retribution }\end{array}$ & 0.490 & 0.309 & 0.119 & 1.587 & 0.116 \\
\hline
\end{tabular}

\subsection{Community and Government Involvement in Household Solid Waste Management}

Community involvement in household solid waste management is seen from community participation as decision maker, implementation, and supervision in household solid waste management. Based on the research results it is known that the involvement of respondents in household solid waste management in Danau Teluk Sub-District, Jambi City can be seen in Table 4.

Table 4 Respondent's Community and Government Involvement in Household Solid Waste

\begin{tabular}{lll} 
& Management Frequency Distribution \\
\hline Decision-making & Frequency (F) & Percentage (\%) \\
\hline Low & 69 & 70 \\
Medium & 29 & 29 \\
High & 1 & 1 \\
\hline Total & 99 & 100 \\
\hline Implementation & Frequency (F) & Percentage (\%) \\
\hline Low & 14 & 14 \\
Medium & 66 & 67 \\
High & 19 & 19 \\
\hline Total & 99 & 100 \\
\hline Supervision & Frequency (F) & Percentage (\%) \\
\hline Low & 18 & 18 \\
Medium & 79 & 80 \\
High & 2 & 2 \\
\hline Total & 99 & 100 \\
\hline Regulator & Frequency (F) & Percentage (\%) \\
\hline Low & 6 & 15 \\
& &
\end{tabular}




\begin{tabular}{lll} 
Medium & 27 & 66 \\
High & 8 & 19 \\
\hline Total & $\mathbf{4 1}$ & $\mathbf{1 0 0}$ \\
\hline Service Provider & Frequency $\mathbf{( F )}$ & Percentage (\%) \\
\hline Low & 5 & 12 \\
Medium & 28 & 68 \\
High & 8 & 20 \\
\hline Total & $\mathbf{4 1}$ & $\mathbf{1 0 0}$ \\
\hline
\end{tabular}

Based on Table 4, it was found that $70 \%$ of respondents with involvement in decision-making were in a low category, $29 \%$ in the medium category, and $1 \%$ in the high category. These results indicate that the respondent's decision-making is low. Respondents dominate respondents' involvement in decision-making in the low category with self-employed jobs and civil servants with high school education. In a study conducted by Yulia (2016), the desire to attend meetings provides ideas and suggestions that indicate the level of public awareness to be actively involved in waste management.

The respondents' involvement in implementing the low category was $14 \%$, respondents in the medium category were $67 \%$, and respondents in the high category were $19 \%$. This condition indicates that the implementation of respondents is relatively high. Respondents dominated respondent's involvement in the medium category with self-employed jobs and civil servants with high school education. In a study conducted by Yulia (2016) that in the implementation process, coordination is needed. The community provides advice to the government and provides advice on the formulation of policies and strategies.

The involvement in supervision in the low category is $18 \%$, the respondents in the medium category are $80 \%$, and the respondents in the high category are $2 \%$. These results indicate that the respondent's supervision of household solid waste management is quite good. Respondents dominate respondents' involvement in the low supervision category with self-employed jobs and civil servants with high school education. In a study conducted by Yulia (2016) that monitoring or evaluation is defined as gathering information (data and facts) and making decisions during the implementation process. Evaluation is an act of decision-making to assess a particular object or activity that is being observed.

The involvement of respondents in the low category of regulators is $15 \%$, respondents in the medium category are $66 \%$, and respondents in the high category are $19 \%$. These facts indicate that the involvement of respondents in regulators on household solid waste management is quite good. Respondents dominated the respondent's involvement in regulators in the medium category with jobs as sub-district head, the village head, and neighborhood head with high school education and a bachelor's degree $\left(\mathrm{S}_{1}\right)$. In a study conducted by Jati (2013), the government's role as a regulator is to make regional regulations, formulate plans, policies, and strategies, and formulate programs.

The involvement of respondents in service providers in the low category is $12 \%$, respondents in the medium category are $68 \%$, and respondents in the high category are $20 \%$. These numbers indicate that respondents' involvement in service providers for household solid waste management is quite good. Respondents dominated respondent's involvement in service providers in the medium category with jobs as head of the village, head of the neighborhood, DLH with education, namely SMA and Bachelor ( $\left.\mathrm{S}_{1}\right)$. In a study conducted by Jati, 2013, the government's role as a service provider is to provide services in the form of waste management infrastructure and create or appoint waste management pilots. Based on research on the involvement of the community and government in the management of household solid waste, there are two involvements in the medium category (good enough), namely implementation, supervision, regulators, and service providers. 


\subsection{Relations between Community and Government Involvement in Household Solid Waste Management on Household Solid Waste Management}

This analysis is used to determine whether there is a relation between the independent and dependent variables. This analysis was performed using the chi-square statistical test. Based on the results of the analysis in Table 5 shows the relation between decision making and household solid waste management, that of 69 respondents with low decision making, $20 \%$ of respondents are in a low category, $77 \%$ of respondents are in the medium category, and 3\% of respondents are in the high category in managing household solid waste. Of the 29 respondents with medium decision-making, $14 \%$ were in a low category, $76 \%$ were in the medium category, and $10 \%$ were in the high category in household solid waste management. From 1 respondent with high decision-making, there are no respondents with low and high categories, and $100 \%$ of respondents in the medium category are in household solid waste management. The results of the chi-square statistical test obtained a p-value of 0.554 (p>0.05), it can be concluded that there is no statistically significant relation between decision making and household solid waste management.

The relation between implementation and household solid waste management shows that of the 14 respondents with low management, $36 \%$ of respondents were in a low category, $64 \%$ were in the medium category, and no respondents were in the high management category household solid waste. Of the 66 respondents with moderate implementation, $20 \%$ were in a low category, $80 \%$ were in the medium category, and no respondents were in the high category in household solid waste management. Of the 19 respondents in the high category, there were no respondents in the low category, $74 \%$ in the medium category, and $26 \%$ in the high category in household solid waste management. The results of the chisquare statistical test obtained a p-value of o.ooo ( $\mathrm{p}<0.05)$, it can be concluded that there is a statistically significant relationship between the implementation of household solid waste management.

The relation between supervision and household solid waste management shows that of the 18 respondents with low supervision, $44 \%$ of respondents were in a low category, $56 \%$ of the respondents were in the medium category, and there were no respondents in the high category in managing household solid waste. Of the 79 respondents with medium supervision, $13 \%$ were in a low category, $82 \%$ were in the medium category, and $5 \%$ were in the high category in household solid waste management. Of the two respondents with high management, there are no respondents in the low category, $50 \%$ in the medium category, and $50 \%$ in the high category in household solid waste management. The results of the chisquare statistical test obtained a p-value of $0.001(\mathrm{p}<0.05)$, it can be concluded that there is a statistically significant relationship between supervision and household solid waste management. Based on research on community involvement in household solid waste management, there are two factors related to household solid waste management, namely implementation, and supervision.

Table 5 Analysis of the Relations between Community Involvement in Household Solid Waste Management

\begin{tabular}{|c|c|c|c|c|c|c|c|c|}
\hline \multirow{3}{*}{ Decision-making } & \multicolumn{5}{|c|}{ Household Solid Waste Management } & & \multirow{2}{*}{ Total } & \multirow[t]{2}{*}{ P-Value } \\
\hline & \multicolumn{2}{|c|}{ Low } & \multicolumn{2}{|c|}{ Medium } & \multicolumn{2}{|l|}{ High } & & \\
\hline & $\mathrm{N}$ & $\%$ & $\mathrm{~N}$ & $\%$ & $\mathrm{~N}$ & $\%$ & & \\
\hline Low & 14 & 20 & 53 & 77 & 2 & 3 & 69 & \\
\hline Medium & 4 & 14 & 22 & 76 & 3 & 10 & 29 & 0,554 \\
\hline High & 0 & 0 & 1 & 100 & 0 & 0 & 1 & \\
\hline \multirow[t]{2}{*}{ Total } & 18 & 18 & 76 & 77 & 5 & 5 & 99 & \\
\hline & \multicolumn{5}{|c|}{ Household Solid Waste Management } & & Totol & P-Value \\
\hline \multirow[t]{2}{*}{ Implementation } & \multicolumn{2}{|c|}{ Low } & \multicolumn{2}{|c|}{ Medium } & High & & Total & \\
\hline & $\mathrm{N}$ & $\%$ & $\mathrm{~N}$ & $\%$ & $\mathrm{~N}$ & $\%$ & & \\
\hline Low & 5 & 36 & 9 & 64 & 0 & 0 & 14 & \\
\hline Medium & 13 & 20 & 53 & 80 & 0 & 0 & 66 & 0.000 \\
\hline
\end{tabular}




\begin{tabular}{|c|c|c|c|c|c|c|c|c|}
\hline High & 0 & 0 & 14 & 74 & 5 & 26 & 19 & \\
\hline Total & 18 & 18 & 76 & 77 & 5 & 5 & 99 & \\
\hline \multirow{3}{*}{ Supervision } & \multicolumn{6}{|c|}{ Household Solid Waste Management } & \multirow{3}{*}{ Total } & \multirow{3}{*}{ P-Value } \\
\hline & \multicolumn{2}{|c|}{ Low } & \multicolumn{2}{|c|}{ Medium } & \multicolumn{2}{|l|}{ High } & & \\
\hline & $\mathrm{N}$ & $\%$ & $\mathrm{~N}$ & $\%$ & $\mathrm{~N}$ & $\%$ & & \\
\hline Low & 8 & 44 & 10 & 56 & 0 & 0 & 18 & \multirow{4}{*}{0.001} \\
\hline Medium & 10 & 13 & 65 & 82 & 4 & 5 & 79 & \\
\hline High & 0 & 0 & 1 & 50 & 1 & 50 & 2 & \\
\hline Total & 18 & 18 & 76 & 77 & 5 & 5 & 99 & \\
\hline
\end{tabular}

\subsection{Household Solid Waste Management Strategy in Danau Teluk Sub-District}

Household solid waste management strategy is an effort to manage household waste so that it is adequately managed and does not pollute the environment. The strategy formulation process in this study begins with looking at the results of the questionnaire and research interviews to find out the problems in Danau Teluk Sub-District and the basis for formulating a SWOT analysis. Based on research in identifying factors, the results of the SWOT analysis are showing in Table 6. Based on Table 6, it can be seen that in the assessment of strength, the highest strength factor in household solid waste management is that waste production is not high, based on DLH data, the generated waste is $8,793.99$ $\mathrm{kg} /$ day, meaning that the waste is easier to manage because the generated generation is not too big. The next strength factor is the willingness to manage household solid waste with ${ }_{3} R s$. The community is willing to manage household solid waste with 3 Rs because it benefits economically and environmentally healthy. This situation can reduce the need and cost of infrastructure for solid waste management households as well as the generation of waste that goes to the the landfill where residue remains. The next strength factor, the availability of garbage drums on the side of the road as many as 76 units can be used by the community as a communal container before waste is collected by waste officers so that it does not cause waste accumulation at the source of waste, this can reduce people's littering and increase waste managed and environmental cleanliness.

Table 6 SWOT Analysis Matrix (Internal Factors)

\section{INTERNAL FACTORS}

\begin{tabular}{|c|c|c|c|c|}
\hline NO. & ASSESSMENT OF STRENGTH (S) & WEIGHT & SCORE & NT \\
\hline 1 & Waste production is not high & 16 & 4 & 70 \\
\hline 2 & Willingness to manage household solid waste with ${ }_{3} \mathrm{R}$ & 16 & 4 & 70 \\
\hline 3 & $\begin{array}{l}\text { Availability of } 76 \text { units of garbage bins (drums) by the } \\
\text { roadside }\end{array}$ & 15 & 4 & 67 \\
\hline 4 & Homogeneous characteristics & 15 & 4 & 60 \\
\hline 5 & $\begin{array}{l}\text { Willingness to pay a household solid waste } \\
\text { management levy }\end{array}$ & 15 & 4 & 59 \\
\hline 6 & $\begin{array}{l}\text { High knowledge in household solid waste } \\
\text { management }\end{array}$ & 13 & 3 & 45 \\
\hline \multirow[t]{2}{*}{7} & Good attitude in household solid waste management & 11 & 3 & 30 \\
\hline & Amount & 100 & & 402 \\
\hline NO. & ASSESSMENT OF WEAKNESSES (W) & WEIGHT & SCORE & NT \\
\hline 1 & No waste bank and TPS ${ }_{3} \mathrm{R}$ & 18 & 5 & 86 \\
\hline 2 & $\begin{array}{l}\text { In-depth socialization regarding household solid waste } \\
\text { management with }{ }_{3} \mathrm{R} \text { is still low }\end{array}$ & 17 & 4 & 72 \\
\hline 3 & $\begin{array}{l}\text { The availability of infrastructure for managing } \\
\text { household solid waste is still low }\end{array}$ & 17 & 4 & 72 \\
\hline
\end{tabular}




\begin{tabular}{lllll}
4 & $\begin{array}{l}\text { Availability of land for TPS construction is still low } \\
5\end{array} \quad \begin{array}{l}17 \\
\text { Availability of access to data and information on } \\
\text { household solid waste management is still low }\end{array}$ & 17 & 4 & 70 \\
$\begin{array}{l}\text { Community culture is difficult to accept input and } \\
\text { changes from outside }\end{array}$ & 17 & 4 & 68 \\
$\begin{array}{l}\text { Availability of means of collection and transportation } \\
\text { of household solid waste is still low }\end{array}$ & 14 & 4 & 52 \\
\hline
\end{tabular}

The next strength factor, homogeneous population characteristics, means that residents have the same racial, ethnic, religious, and cultural identity and follow a lifestyle with the same cultural character. This result impacts the type of waste produced so that it is not too diverse and easier to manage and adjust to the type of waste. The next strength factor is the willingness to pay retribution from the community, meaning that the community is willing to improve household solid waste management services because there is a desire to improve waste services, and there are concerns from the community about increasing waste production in the future, this has an impact on improving services and better waste infrastructure facilities. The next strength factor, knowledge and attitude of the community towards household solid waste management, means that in this case, the community has the most basic understanding and attitude regarding household solid waste management. This condition impacts how the community manages household solid waste, which is expected to be environmentally friendly.

In assessing weaknesses, the highest weakness factor in household solid waste management is that there are no waste banks and ${ }_{3} \mathrm{R}$ TPS, meaning that people do not consider waste. processing a priority in handling waste or do not understand household solid waste processing. This situation impacts people interested in processing household solid waste who do not have access to facilities and infrastructure to carry out further processing of household solid waste. The next weakness factor, indepth socialization of household solid waste management with ${ }_{3} \mathrm{R}$, is still low, carried out at the subdistrict level, and only a few are carried out at the urban village/neighborhood level so that only some people are exposed to information about household solid waste management.

The next weakness factor is that the availability of infrastructure to manage disaggregated household solid waste is still low. In particular, the facilities and infrastructure for the new segregated container are provided in several areas, such as offices that are not yet located in residential areas. It takes awareness from the community and the government to start sorting waste from the source. The availability of land for TPS construction is still low because most of the land has been used as a community settlement area, and the community is not willing if the land is used for TPS because it will disturb the aesthetics of the environment and public health. This condition impacts the lack of temporary waste collection sites, and the community throws trash anywhere. There is not a single conventional polling station in Danau Teluk Sub-District.

The availability of access to data and information on household solid waste management is still low. In this case, there is no complete data and information on solid waste at the sub-district to neighborhood levels. The community needs this in terms of understanding the management of household solid waste. The next weakness factor is that the culture of the community is difficult to accept input and changes from outside of the community tends to be a little apathetic to receive input from outside because they are used to existing conditions, this has an impact on the absorption of information regarding household solid waste management.

The next weakness factor, the availability of means of collecting and transporting the household solid waste, is still low, in this case, the collection tool is only a $1 \mathrm{~m}_{3}$ motorized cart with 1 unit to serve 1 sub-district, and the means of transport is only a $6 \mathrm{~m} 3$ dump truck with 1 unit with each cycle twice per day, this has an impact on the amount of waste that is managed. Based on the total value, it is known that 
the strengths are 402 while the weaknesses are 491 . The difference between strengths and weaknesses is -89, which means that the strength factor is not more dominant than the weaknesses possessed.

Table 7 SWOT Analysis Matrix (External Factors)

\begin{tabular}{|c|c|c|c|c|}
\hline \multicolumn{5}{|c|}{ EXTERNAL FACTORS } \\
\hline NO. & OPPORTUNITY ASSESSMENT (O) & WEIGHT & SCORE & NT \\
\hline 1 & $\begin{array}{l}\text { There are policies and strategies for household solid waste } \\
\text { management that support }\end{array}$ & 28 & 5 & 130 \\
\hline 2 & $\begin{array}{l}\text { There is socialization of local regulations with waste } \\
\text { management training media from the government }\end{array}$ & 26 & 4 & 106 \\
\hline 3 & $\begin{array}{l}\text { There are business people in waste management such as } \\
\text { waste processors and collectors }\end{array}$ & 25 & 4 & 100 \\
\hline 4 & Availability of APBD funds for waste management & 21 & 3 & 72 \\
\hline & Amount & 100 & & 408 \\
\hline NO. & THREAT ASSESSMENT (T) & WEIGHT & SCORE & NT \\
\hline 1 & Flood-prone areas every 6 months & 53 & 5 & 247 \\
\hline 2 & $\begin{array}{l}\text { An increase in the volume of waste by about } 10 \% \text { has a } \\
\text { negative impact on the environment }\end{array}$ & 47 & 4 & 190 \\
\hline & Amount & 100 & & 438 \\
\hline
\end{tabular}

It can be seen in Table 7 that the highest opportunity factor in the management of household solid waste is that there are policies and strategies for managing household solid waste that supports the existence of policies and strategies for managing household solid waste that support the relevant agencies contained in the Jambi City Perda No. 8 of 2013 concerning Waste Management. Policies and strategies lead to waste reduction and handling programs/activities. The next opportunity factor is the socialization of local regulations with waste management training media from the government, which is carried out every 3 years by conducting waste management training with ${ }_{3}$ Rs such as composting and the use of inorganic waste into crafts well as socializing local regulations.

The next opportunity factor is that business people in waste management, such as waste processors and collectors, use waste to run their business. This opportunity can form cooperation between the community and business people so that waste can be managed and business people and the community can get economic benefits. The next opportunity factor is the availability of APBD funds for waste management from the government. The availability of sufficient funds has a vital role in household solid waste management to meet financing in household solid waste management.

In the threat assessment, there are the highest threat factors in household solid waste management, namely areas prone to flooding. Flooding occurs every 6 months. If household solid waste management is not carried out properly, there will be a risk that waste that is not managed correctly can be carried away by floods and disrupt public health and environmental aesthetics. The next threat factor is that the addition of about $10 \%$ of the volume of waste harms the environment. An increase in the volume of waste without being accompanied by an increase in household solid waste management will impact waste that is not managed correctly and continues to increase. 


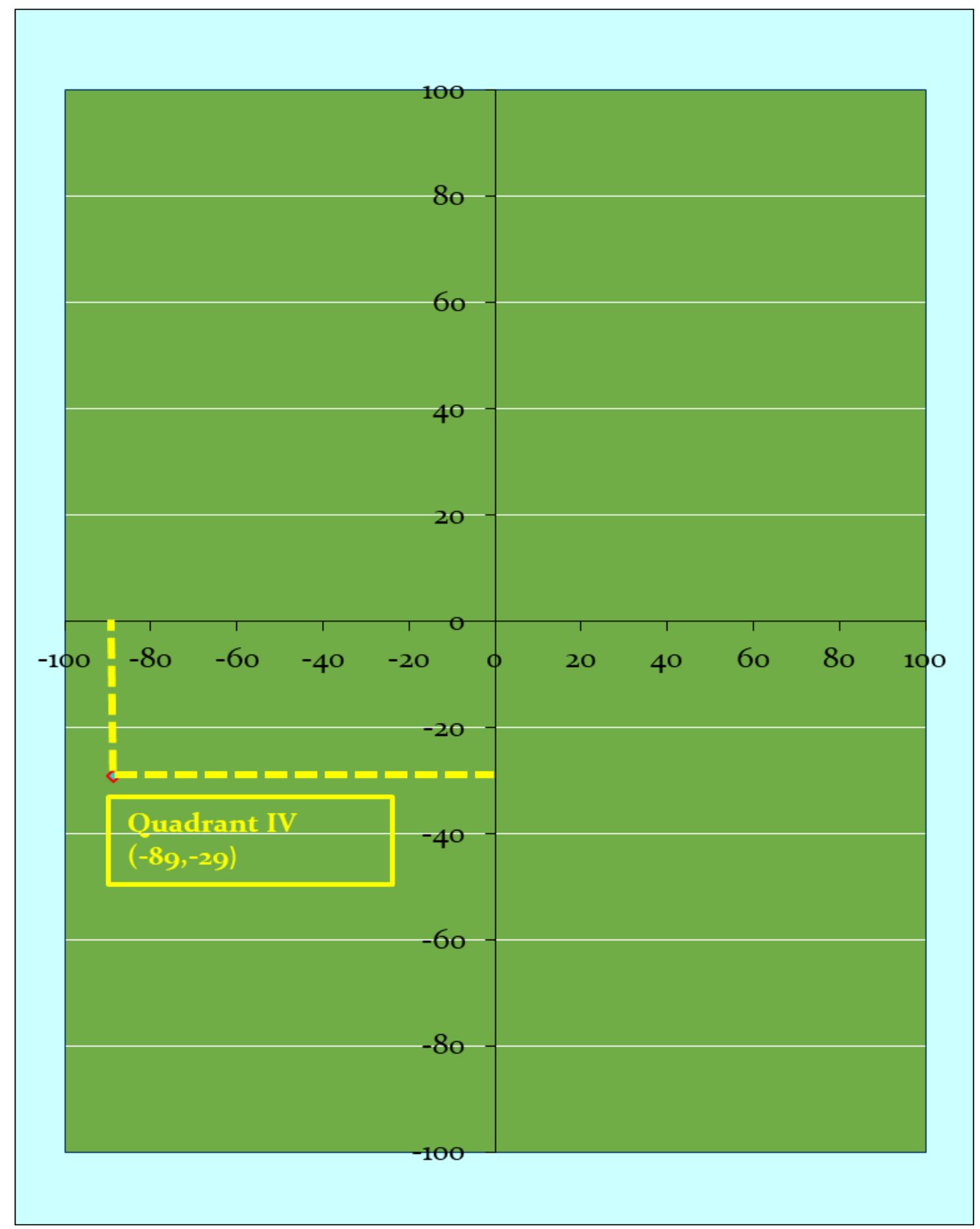

Figure 1 Position of the SWOT Quadrant Strategy

Based on the total value, it is known that the opportunities are 408 while the threats are 438 . The difference between strengths and weaknesses is $\mathbf{- 2 9}$, which means that the opportunity factor is not more dominant than the threat factor, so that the strategic position in the SWOT analysis is shown in Figure 1. Based on Figure 1, it can be seen that the position of the assessment of internal and external factors is in quadrant IV (negative, negative) internal weaknesses and threats. With this position, the supportive strategy is defensive, a technique to defend by reducing internal weaknesses and avoiding threats. Several strategies can be used in carrying out household solid waste management in Danau Teluk Sub-District, Jambi City, to be optimal, as shown in the SWOT matrix in Table 8. 
Table 8 Matrix of Household Solid Waste Management Strategy in Danau Teluk Sub-District, Jambi

City

\begin{tabular}{|c|c|c|c|c|c|}
\hline \multirow{8}{*}{\multicolumn{2}{|c|}{ INTERNAL FACTORS }} & No. & Strength $(\mathbf{S})$ & No. & Weaknesses $(\mathrm{W})$ \\
\hline & & 1 & Waste production is not high & 1 & No waste bank and TPS 3R \\
\hline & & 2 & $\begin{array}{l}\text { Willingness to manage } \\
\text { household solid waste with 3R }\end{array}$ & 2 & $\begin{array}{l}\text { In-depth socialization } \\
\text { regarding household solid waste } \\
\text { management with 3R is } \\
\text { still low }\end{array}$ \\
\hline & & 3 & $\begin{array}{l}\text { Availability of } 76 \text { units of } \\
\text { garbage bins (drums) by the } \\
\text { roadside }\end{array}$ & 3 & $\begin{array}{l}\text { The availability of } \\
\text { infrastructure for managing } \\
\text { household solid waste is still } \\
\text { low }\end{array}$ \\
\hline & & 4 & Homogeneous characteristics & 4 & $\begin{array}{l}\text { Availability of land for TPS } \\
\text { construction is still low }\end{array}$ \\
\hline & & 5 & $\begin{array}{l}\text { Willingness to pay a household } \\
\text { solid waste management levy }\end{array}$ & 5 & $\begin{array}{l}\text { Availability of access to data } \\
\text { and information on household } \\
\text { solid waste } \\
\text { management is still low }\end{array}$ \\
\hline & & 6 & $\begin{array}{l}\text { High knowledge in household } \\
\text { solid waste management }\end{array}$ & 6 & $\begin{array}{l}\text { Community culture is } \\
\text { difficult to accept input and } \\
\text { changes from outside }\end{array}$ \\
\hline & & 7 & $\begin{array}{l}\text { Good attitude in household } \\
\text { solid waste management }\end{array}$ & 7 & $\begin{array}{l}\text { Availability of means of } \\
\text { collection and transportation of } \\
\text { household solid waste is } \\
\text { still low }\end{array}$ \\
\hline No. & $\frac{\text { Opportunities }}{\underline{(\mathbf{O})}}$ & & $\underline{\text { SO Strategy }}$ & & WO Strategy \\
\hline 1 & $\begin{array}{l}\text { There are policies } \\
\text { and strategies for } \\
\text { household solid } \\
\text { waste management } \\
\text { thatsupport }\end{array}$ & 1 & $\begin{array}{l}\text { Fully support community } \\
\text { participation in the } 3 \mathrm{Rs} \text { by } \\
\text { conducting socialization and } \\
\text { training on household solid } \\
\text { waste management from the } \\
\text { sub-district } \\
\text { neighborhood levels (S2O2) }\end{array}$ & 1 & $\begin{array}{l}\text { Provide adequate segregated } \\
\text { household solid waste } \\
\text { management facilities and } \\
\text { infrastructure in the community } \\
\text { (W3O4) }\end{array}$ \\
\hline 2 & $\begin{array}{l}\text { There is } \\
\text { socialization of } \\
\text { local regulations } \\
\text { with waste } \\
\text { management } \\
\text { training media } \\
\text { from government the } \\
\text { gove }\end{array}$ & 2 & $\begin{array}{l}\text { Implementing a policy to make } \\
\text { mandatory use of theavailability } \\
\text { of roadside trash bins for } \\
\text { temporary waste disposal sites } \\
(\mathrm{S} 3 \mathrm{O} 1)\end{array}$ & 2 & $\begin{array}{l}\text { Create a waste management } \\
\text { model with depot transfers } \\
\text { without TPS so that household } \\
\text { solid waste management runs } \\
\text { more effectively and efficiently } \\
\text { (W4O1) }\end{array}$ \\
\hline
\end{tabular}




\begin{tabular}{|c|c|c|c|c|c|}
\hline 3 & $\begin{array}{l}\text { There } \\
\text { business people in } \\
\text { waste } \\
\text { management such } \\
\text { as waste } \\
\text { processors and } \\
\text { collectors }\end{array}$ & 3 & $\begin{array}{l}\text { Collaborate with waste } \\
\text { processing and collector } \\
\text { businesses to increase the } \\
\text { efficiency of household solid } \\
\text { waste management results } \\
\text { (S3O3) }\end{array}$ & 3 & $\begin{array}{l}\text { Conducting socialization to the } \\
\text { community regarding examples } \\
\text { of household solid waste } \\
\text { management that have been } \\
\text { running and are thriving } \\
\text { (W6O2) }\end{array}$ \\
\hline 4 & $\begin{array}{l}\text { Availability of } \\
\text { APBD funds for } \\
\text { waste } \\
\text { management }\end{array}$ & 4 & $\begin{array}{l}\text { Utilizing the community's } \\
\text { willingness to pay retributionto } \\
\text { increase the APBD on } \\
\text { waste (S5O4) }\end{array}$ & & \\
\hline & Threats (T) & & ST strategy & & WT Strategy \\
\hline 1 & $\begin{array}{l}\text { Flood-prone areas } \\
\text { every ix } \\
\text { months }\end{array}$ & 1 & $\begin{array}{l}\text { Conducting socialization to the } \\
\text { public regarding good } \\
\text { environmental sanitation, } \\
\text { especially in managing } \\
\text { household solid waste such as } \\
\text { maximum waste residence time, } \\
\text { good location of garbage bins, } \\
\text { the impact of waste } \\
\text { (S7T1) }\end{array}$ & 1 & $\begin{array}{l}\text { Reducing waste starting at the } \\
\text { source by reducing the use of } \\
\text { goods that produce waste } \\
\text { (W3T1) }\end{array}$ \\
\hline 2 & $\begin{array}{l}\text { An increase in the } \\
\text { volume of wasteby } \\
\text { about } 10 \% \text { harms } \\
\text { the } \\
\text { environment }\end{array}$ & 2 & $\begin{array}{l}\text { Manage household solid waste } \\
\text { with the } 3 \mathrm{R} \text { principle for the } \\
\text { waste generation to the landfill } \\
\text { (S2T2) }\end{array}$ & 2 & $\begin{array}{l}\text { Provide information data about } \\
\text { waste managementthat is easily } \\
\text { accessible by thepublic, such as } \\
\text { social media, websites, } \\
\text { television advertisements, } \\
\text { bulletin } \\
\text { boards. (W2T2) }\end{array}$ \\
\hline
\end{tabular}

Based on the results of the SWOT analysis matrix assessment above, strategic priorities can be formulated so that the management of household solid waste in the Danau Teluk Sub-District to be more optimal, including:

- Fully support community participation in the 3 Rs. By conducting socialization and training on household solid waste management from the sub-district level to the neighborhood $\left(\mathrm{S}_{2} \mathrm{O}_{2}\right)$. One of the determinants in household solid waste management is the participation of the community, involving the community to participate in managing waste starting from sorting organic and inorganic waste and processing organic waste using a household composter, and involving managers from the local community to recycling of inorganic waste and composting on an environmental scale. Based on Permenpu No. 3 of 2013, the implementation of 3 R activities is based on community needs. ${ }_{3} \mathrm{R}$ activities focus on waste management at the source, and socialization/activities campaigns are still being carried out. The government can carry out socialization from the sub-district to neighborhood levels, which is expected to make all levels of society absorb information about the importance of implementing household solid waste management and implementing 3 Rs.

- Implement a policy to be obliged to utilize the availability of garbage bins on the side of the road for temporary waste disposal $\left(\mathrm{S}_{3} \mathrm{O}_{1}\right)$. Perda No. 8 of 2013, there is a prohibition for any person/body to throw, pile up, store on roads, green lanes, parks, rivers, public facilities, and other similar places, and dispose of waste outside the designated disposal site or location. By following the communal receptacle requirements set by SNI 19-2454-2002, namely trash in the 
form of boxes, cylinders, containers, bins (barrels) with lids that are lightweight, easy to move, and emptied and made of metal, plastic, fiberglass, wood, bamboo, rattan with sizes for roadside and garden 30-40 liters. It is hoped that it will make the community use the availability of garbage bins properly.

- Cooperate with waste processing and collector businesses to improve household solid waste management results $\left(\mathrm{S}_{3} \mathrm{O}_{3}\right)$. The community cooperates with third parties to sell the waste they have managed to be of the sale value and be economically beneficial. Able to increase income for the community and business people processing and collecting waste.

- Take advantage of the community's willingness to pay retribution to increase the APBD on waste $\left(\mathrm{S}_{5} \mathrm{O}_{4}\right)$. The determining factor for the operational quality of waste management services is retribution. In Perda No. 8 of 2013, the government is obliged to provide services in the field of waste by collecting retribution for waste/cleaning services. By increasing the APBD from community levies, it can be used to increase waste handling service activities, provide waste collection facilities, restore the environment due to waste handling activities, as well as increase the competence of waste management so that household solid waste management can be implemented properly.

- $\quad$ Provide adequate segregated household solid waste management facilities and infrastructure in the community $\left(\mathrm{W}_{3} \mathrm{O}_{4}\right)$. Factors affecting waste management are means of collection, transportation, processing, and final disposal of waste. In PP RI No. 81 of 2012 that collection and transportation tools are provided, including segregated waste. The available infrastructure facilities need to be improved to support community involvement in household solid waste management. So that people who have done waste sorting can further process the results of the sorting in household solid waste management activities. With the calculation of SNI 3242-2008, the waste collection tools contained in the form of $1 \mathrm{~m} 3$ motorized carts as much as 1 unit with recitation 2 times per day based on the calculation of the ideal equipment needs of 12 units of motorized carts; The means of transporting waste in the form of a dump truck of $6 \mathrm{~m} 31$ unit with 2 cycles per day based on the calculation of the need for equipment, ideally 2 units or an increase in transportation traffic.

- Create a waste management model with depot transfers without TPS to run household solid waste effectively and efficiently $\left(\mathrm{W}_{4} \mathrm{O}_{1}\right)$. There is no TPS because the land for making TPS has been made for residential land. There is already a transfer depot that meets the requirements based on SNI 19-2454-200, which is easy to enter for waste collection and transport facilities and not far from the waste source. Based on its type, namely, type III transfer depo, where its function is as a meeting place for carts and 6-10 $\mathrm{m}_{3}$ containers, it is suitable for areas where it is difficult to get vacant land. It is better if the transfer depot is not only used as a meeting place for transportation and gathering tools but can also be used as a parking lot for carts and sorting waste.

- It is conducting socialization to the community regarding examples of household solid waste management that have been running and are thriving (W6O2). People tend to find it difficult to accept change. This situation can be overcome by providing socialization to the community regarding examples of household solid waste management in an area that has been running and has worked well so that waste management can be appropriately managed per Jambi City Perda No. 8 of 2013. The government can plan socialization activities with resource persons from the office or person in charge of household solid waste management in the area that has been running and successfully carried out on an ongoing basis.

- Government can conduct socialization to the community regarding good environmental sanitation, especially in household solid waste management, such as maximum waste residence time, good location of trash bins, the impact of waste $\left(\mathrm{S}_{7} \mathrm{~T}_{1}\right)$. A common problem related to waste management is the danger of not managing waste. This socialization changes the community's 
mindset in maintaining health and managing waste originating from the household environment. The importance of this activity is so that people who are less aware and understand in maintaining the health and cleanliness of their environment know how important it is to keep themselves and their surroundings clean. Socialization is conducted by providing related information for the residence time of organic waste types 1 day and inorganic 3 days. Waste storage should not pollute the environment. The requirements include water and airtightness, easy cleaning, having a lid to be hygienic, and the volume of waste according to type, related to the impact of indiscriminate disposal of waste that will impact public health environmental hygiene.

- Manage household solid waste with the ${ }_{3} \mathrm{R}$ principle for the waste generation to the landfill ( $\mathrm{S}_{2} \mathrm{~T}_{2}$ ) and reduce waste starting from the source by reducing the use of goods that produce waste (W3T1). In UU No. 18 of 2008 , everyone is obliged to carry out three main activities in implementing waste reduction activities: limiting waste generation, recycling waste, and reusing waste. These three activities embody the environmentally sound waste management principle called ${ }_{3} \mathrm{R}$ (reduce, reuse, recycle). The benefit of managing household solid waste with the ${ }_{3} \mathrm{R}$ principle is that the waste generated from the source can be directly managed without adding the waste generated at the landfill so that the waste in the landfill only remains. This condition can reduce the need and cost of household solid waste management facilities and infrastructure.

- Provide information data about waste management that is easily accessible by the public, such as social media, websites, television advertisements, and bulletin boards (W2 2 2). In PP RI 18 of 2012, the government provides information on household solid waste management by providing information on the source, generation, composition, characteristics, facilities, and other household's solid waste management information. This information must be accessible to the entire community. This information can be disseminated through social media, websites, television advertisements, and bulletin boards placed at the sub-district and sub-district offices as a basis for public knowledge to manage household solid waste

\section{Conclusions}

Based on the research results, the factors that influence household solid waste management in the Danau Teluk Sub-District are factors with the highest category, namely the willingness to pay retribution. Two factors influence household solid waste management, namely behavior and knowledge of local regulations, with knowledge of local regulations having the most dominant influence. Community and government involvement in household solid waste management in Danau Teluk Sub-district has moderate (reasonably good) category involvement, namely implementation, supervision, regulators, and service providers. There are two factors related to the management of household solid waste, namely the implementation and supervision. The strategy that can be applied in Danau Teluk Sub-District, Jambi City, is defensive, namely reducing waste starting from the source by reducing the use of goods that produce waste and providing information data about waste management that is easily accessible to the public such as through social media, websites, television advertisements, and bulletin boards.

\section{References}

Artiningsih, N.K. 2008. Community Participation in Household Waste Management (Case Study in Sampangan and Jomblang, Semarang City)". Thesis, Diponegoro University

Jambi City Environment Agency. 2016. Jambi City Master Plan. Jambi: Jambi City Environmental Service. Jambi City Environment Agency. 2020. Waste Handled 2019. Jambi: Jambi City Environmental Service. Ghozali, I. 2011. Multivariate Analysis Application With SPSS Program. Semarang: Diponegoro University Publishing Agency.

Jati, T.K . 2013. The Role of Boyolali Government in Urban Settlement Environmental Waste Management. Environmental Area Journal 1(1), 1-16. 
Jumar. 2014. Household Waste Management Strategy in Lok Bahu Village, Sungai Kunjang District, Samarinda City. Journal of Administrative Reform 2(1), 101-112.

Kadir. 2015. Applied Statistics. Depok: PT RajaGrafindo Persada.

Danau Teluk Sub-District Head Office. 2021. Waste Management Infrastructure Data. Jambi.

Minister For Public Works and Human Settlements. 2013. Permenpupr Number 3 of 2013: Implementation of Waste Infrastructure and Facilities in the Handling of Household Waste and Waste Similar to Household Waste. Jakarta: Ministry of Public Works and Public Housing.

Marleni, Y. 2012. Household Waste Management Strategy in Medan City Village, Manna City District, South Bengkulu Regency. Journal of Natural Resource Management and Environmental Research.

Muchsin, T. 2017. The Role of Village Governments in Waste Management Perspective of Perda Number 2 of 2015 concerning Waste Management. Journal of Legal Studies 5(4), 72-90.

Nawawi, H. 200o. Strategy Management. Yogyakarta: UGM Press.

Jambi City Government. 2013. Jambi City Perda Number 8 of 2013: Waste Management. Jambi: Regional Government of Jambi City.

Jambi City Government. 2018. Jambi City Perwali Number 54 of 2018: Jambi City Policies and Strategies in the Management of Household Waste and Waste Similar to Household Waste. Jambi: Regional Government of Jambi City.

Jambi City Government. 2018. Jambi City Perwali Number 61 of 2018: Restrictions on the Use of Plastic Shopping Bags. Jambi: Jambi City Government.

Government of the Republic of Indonesia. 2008. UU No. 18 of 2008: Waste Management. Jakarta: Government of the Republic of Indonesia.

Government of the Republic of Indonesia. 2012. PP RI Number 81 of 2012: Management of Household Waste and Similar Waste of Household Waste. Jakarta: Government of the Republic of Indonesia.

Perpres RI Number 97 of 2017: National Policies and Strategies for the Management of Household Waste and Waste Similar to Household Waste. 2017. Jakarta: Government of the Republic of Indonesia.

Riswan, Sunoko, H.R, \& Hadiyarto, A. 2011. Household Waste Management in South Daha District. Journal of Environmental Science 9(1), 31-39.

Santosa, B., \& Ashari. 2005. Statistical Analysis with Microsoft Excel and SPSS. Yogyakarta: Publisher Andi.

Sugiyono. 2017. Educational Research Methods Approach Quantitative, Qualitative, and R \& D. Bandung: Alfabeta.

Suliyanto. 2014. Non Parametric Statistics. Yogyakarta: Andi Offset.

Syamaun, S. 2019. The Influence of Culture on Religious Attitudes and Behavior. Journal of At-Taujih 2(2), 81-95.

Widiarti, I.W. 2012. Waste Management Based on "Zero Waste" Household Scale. Journal of Environmental Science and Technology 4(2), 101-113.

Wintoko, B. 2012. Practical Guide to Establishing a Waste Bank (Dual Benefits of a Clean Environment and Financial Security). Yogyakarta: New Press Library. 